\title{
How Does Corporate Party Committee Governance Affect Charitable Donations? Evidence from Heavy-Pollution Industries in China
}

\author{
Huiming Zhang ${ }^{1, *}$, Lirong $\mathrm{Li}^{1}$, Cheng Fan ${ }^{1}$, Zixuan Hang ${ }^{2}$ and Haroon ur Rashid Khan ${ }^{1}$ \\ 1 School of Management Science and Engineering, Nanjing University of Information Science \& Technology, \\ Nanjing 210044, China; 20191224004@nuist.edu.cn (L.L.); 15229045396@163.com (C.F.); \\ harunkhan1@gmail.com (H.u.R.K.) \\ 2 School of Applied Meteorology, Nanjing University of Information Science \& Technology, \\ Nanjing 210044, China; 202013420025@nuist.edu.cn \\ * Correspondence: 002068@nuist.edu.cn; Tel.: +86-13914741963
}

\section{check for} updates

Citation: Zhang, H.; Li, L.; Fan, C.; Hang, Z.; Khan, H.u.R. How Does Corporate Party Committee Governance Affect Charitable Donations? Evidence from Heavy-Pollution Industries in China. Sustainability 2021, 13, 12242. https:/ / doi.org/10.3390/su132112242

Academic Editors: Xiaohang Ren,

Yukun Shi, Kun Duan and

Cheng Cheng

Received: 12 September 2021

Accepted: 21 October 2021

Published: 5 November 2021

Publisher's Note: MDPI stays neutral with regard to jurisdictional claims in published maps and institutional affiliations.

Copyright: (c) 2021 by the authors. Licensee MDPI, Basel, Switzerland. This article is an open access article distributed under the terms and conditions of the Creative Commons Attribution (CC BY) license (https:/ / creativecommons.org/licenses/by/ $4.0 /)$.

\begin{abstract}
Charitable donations are an effective way for heavy-pollution industries to reduce their environmental reputation risk. In China, the communist party committees within corporations play a key role in decisions regarding charitable donations. However, relatively little is known about the relationship between the governance of corporate party committees and charitable donations. Using data from Chinese listed firms in heavy-pollution industries from 2013 to 2018, we found that corporate party committee governance enhanced the willingness of firms to donate and to increase the amount of their donations significantly. The effect on intention of charitable donations was pronounced for non-state-owned enterprises (NSOEs), whereas the effect on the amount of donations was pronounced for state-owned enterprises (SOEs). Party committee governance increased the amount of charitable donations in regions with a higher level of marketization, but it reduced the amount of charitable donations in firms/industries with a high degree of monopoly. Our findings provide insight for the decisive role of party committees in corporate charitable donations in heavypollution industries.
\end{abstract}

Keywords: corporate party committee governance; heavy-pollution industries; corporate donations; heterogeneity test; marketization level; monopoly strength

\section{Introduction}

In the report of the 19th National Congress of the Communist Party of China (CPC), General Secretary Xi Jinping pointed out that "Grassroots party organization is critical for ensuring the implementation of the party's targets, principles, policies, decisions and arrangements. We should focus on improving organizational capacity, give priority to political functions, and turn community-level party organizations, such as enterprises, into strong fortresses for disseminating the party's propositions". Grassroots party organization, which is the basic unit of the party's organization, is the propagator and practitioner of the organizational ideology of the party. For any company based in China, a party organization must be embedded in the corporate governance structure, which is an inevitable requirement. Specifically, this applies to heavy-pollution industries, such as coal, steel, and other fields, which are related to national security. These corporate communist party committees have developed enthusiastically.

In recent years, frequent environmental pollution incidents have aroused great concern. Production by heavy-pollution firms exerts serious negative externalities to the environment, and thus public opinion suggests that they should assume greater social responsibility and compensate the public for their negative impact through charitable donations. For this reason, mining, oil, and tobacco companies have strengthened their charitable donations to maintain a high-quality corporate image and to accumulate moral 
capital [1]. During the COVID-19 pandemic, many heavy-pollution companies participated actively through charitable donations. According to the statistics of the Petrochemical Federation, as of 16 February 2021, 636 petrochemical enterprises, which included Hengli Group, Petro China, and Sinopec, had donated 1.35 billion CNY. As an important corporate decision, it is of great significance to explore whether charitable donations of heavypollution enterprises were affected by corporate party committee governance in addition to corporate governance guidelines, the institutional environment, and other factors.

Prior studies have shown that corporate party committee governance had an impact on tax avoidance, demonstration of social responsibility, executive compensation, and loss of state-owned assets. However, there is a lack of studies on the influence of corporate party committee governance on charitable donations, specifically, in heavy-pollution enterprises. Communist party committees are embedded in the corporate governance structure in the following way: the secretary of the party committee (party leading group) and the chairman of the board are positions that are held by the same person. Party committee members are elected to the board of directors, the board of supervisors, and the management group through legal procedures in accordance with regulations. Will this arrangement with respect to party committee governance affect the company's charitable donations? Are there any significant differences in charitable donations that vary with corporate ownership? Our study aims to investigate the effects of party committee governance on charitable donation behavior by heavy-pollution firms and the possible mediation mechanisms, which should shed light on the drivers of corporate charitable donations.

We found that corporate party committee governance increased the willingness to donate and the amount of donations significantly in heavy-pollution industries. The heterogeneity test of a company's ownership showed that corporate party committee governance exerted a more significant positive effect on non-state-owned enterprises (NSOEs) in terms of their intention to donate. By contrast, corporate party committee governance affected charitable donations more significantly for state-owned enterprises (SOEs) in terms of the amount of donations. Party committee governance increased the amount of charitable donations in regions with a higher level of marketization, but it reduced the amount of charitable donations in firms with a high degree of monopoly.

Our study contributes three elements to the literature. First, we extend current studies on the relationship between corporate party committee governance and charitable donations for specific industries. This will be conducive to the sustainable development of heavy-pollution industries. Second, we provide a new understanding of the driving factors of corporate charitable donations. Previous studies focused on driving factors of charitable donations, such as corporate governance, financial status, and characteristics of senior management, instead of corporate party committee governance. Our study reflects the Chinese features of corporate governance decision-making and enriches the study on corporate social responsibility. Finally, we investigate the effect of the external macroenvironment on corporate charitable donations by examining two sub-samples: the market environment (marketization level) and the industry environment (monopoly strength). This provides insight into the policies of charitable donations within the heavy-pollution industries under different macro-environments.

The remainder of the paper is organized as follows. Section 2 analyzes the institutional background and puts forward research hypotheses. Section 3 describes the data and methodology. Section 4 reports empirical results. Section 5 conducts several robustness tests. Section 6 presents the conclusions and policy implications.

\section{Institutional Background and Development of Hypotheses}

\subsection{Institutional Background}

In China, the Company Law and the Constitution of the Communist Party of China stipulated that "firms, rural areas, government organs, schools, research institutes and other grass-roots units, where there are more than three full party members, should establish the primary-level party committees. The primary-level party committees in SOEs and collec- 
tive enterprises should serve the production and operation, ensuring that the policies of the party and the country be implemented in the firms. In non-public economic organizations, the primary-level party committees implement the party's guidelines and policies, and supervise enterprises in complying with the laws and regulations of the country." This provision endowed party committees with the legal function to participate in business decision-making.

Charitable donation, which is a part of business decision-making, helps to alleviate social conflicts and to narrow the gap between rich and poor, which is consistent with the CPC's mission of serving the people completely. By establishing party committees, these values of party service can be transformed into corporate culture, which directly affect corporate donation strategies. Moreover, the supervisory function of party committees can reduce agency barriers and ensure the conduct of charitable donations. Due to the distinct political attributes of $\mathrm{SOE}$, the participation of party committees in corporate governance was first implemented in SOEs. The report of the 18th National Congress stated that "comprehensively promoting the basic-level party construction in all fields, expand the coverage of party organization and party duty". As a result of this, strengthening communist party construction in non-public firms has become a governmental requirement, and China has issued a series of policies to lead companies to implement party construction (see Table 1).

Table 1. Provisions for corporate party committee governance in China.

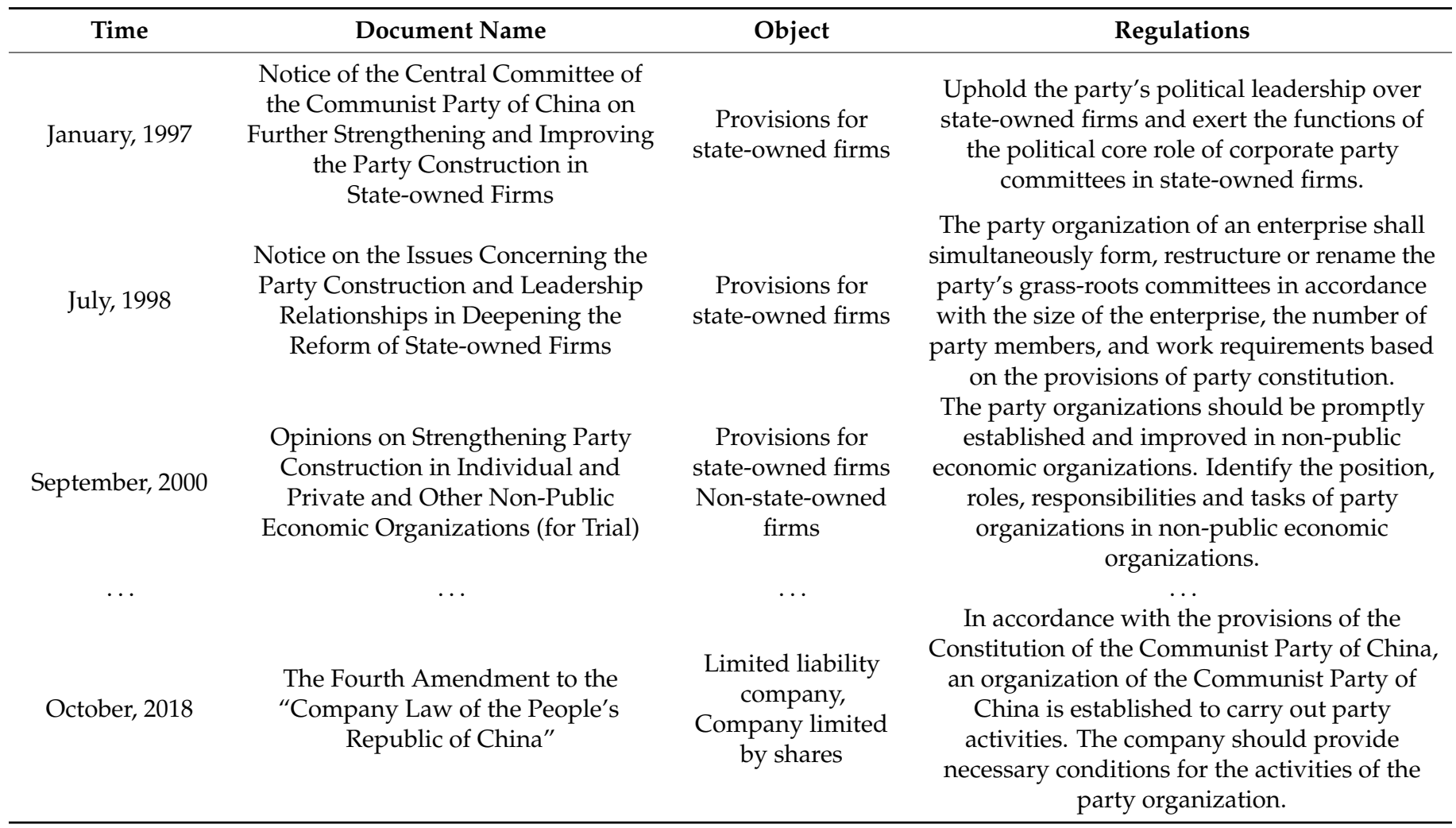

\subsection{Development of Hypotheses}

A number of studies explore the altruistic motivation for corporate charitable donations. For example, Campbell et al. [2] proposed that firms would carry out "pro-social behaviors", such as charitable donations, out of altruistic motives to assume their responsibility as "corporate citizens" actively. Even if the donation did not bring financial returns to the company, the company should continue this behavior [3]. Other studies that investigated the altruistic motivations focused on religious culture [4] and the poverty experience of senior executives [5]. The hypothesis of rational man suggests that each 
person engaged in economic activity is self-interested, and that maximization of their own value is the ultimate goal of companies. Charitable donations are potentially profitable and help to achieve this goal in the long run. Corporate donations, which were an effective marketing strategy [6], sent reputation signals to consumers [7], influenced consumers' beliefs and attitudes towards enterprise products [8], and influenced consumer behavior significantly [9]. All these were powerful factors to maintain the company's image and reputation by enhancing brand awareness and consumer loyalty [10], which ultimately resulted in improving its ability to compete with other enterprises [11] and to increase enterprise value [12]. In addition, corporate charitable donations helped enterprises to accumulate moral capital and to reduce reputation risk [13-15]. When a firm encountered a crisis, charitable donations, as a crisis management and reputation compensation strategy [16], gained the understanding and support of stakeholders.

Corporate charitable donations also have political motives [17]. In China, the government controls some key resources that influence the development of enterprises [18,19]. Corporate charitable donations can be a strategy of "political contributions", and they are conducive to establishing political connections and obtaining benefits, such as investment opportunities, financing facilities, and government subsidies [20]. The political motives have been supported by the literature of [21,22].

Several studies explore the effectiveness of corporate party committees on financial performance, corporate social responsibility, and corporate governance. Chang and Wong [23] found that weakening the power of the party committee in decision-making was conductive to improving corporate performance. Chen and $\mathrm{Lu}$ [24] revealed that the participation of corporate party committees in governance curbed the potential "loss of state-owned assets" effectively. According to Guo et al.'s [25] viewpoints, the degree of overlap between members of the party committee and directors has a converted U-shape relationship with firm performance. In contrast to state-owned firms, whether party committee governance exerted influence on private companies has received little attention [26]. Related research includes Gustafsson et al. [27] and Yu et al. [28].

As a strong institutional force, party organizations strengthen social supervision and prevent non-socially responsible behaviors of companies effectively [29]. Charitable donations, which involve a specific corporate decision, are influenced directly by corporate executives. Hambrick and Mason [30] pointed out in the upper echelons theory that the characteristics of managers affected their corporate strategies. In private firms, the political ideology of corporate managers and founders had a profound impact on the company's operating decisions and cultural shaping [31]. This, in turn, affected the viewpoints toward corporate social responsibility. The deeper an entrepreneur's awareness of social responsibility was, the better he fulfilled social responsibility. By receiving advanced cultural education from the party, an entrepreneur can arouse their own political awareness, which enables executives to assume social responsibility while pursuing economic interests. Then, executives would have both the motivation and the ability to fulfill the will of the party in the company's business decision-making. Additionally, while holding leadership positions within the party, leaders can participate actively in charitable donations out of the need to maintain their political roles. Based on the above analysis, these hypotheses are proposed:

Hypothesis 1. Party committee governance significantly enhances corporate willingness to donate and increases the amount of the donations, all else being equal.

Property rights have a significant impact on the enterprise's resource allocation, shareholding structure, agency strategies, and management mechanisms [32]. Compared with the close relationship between SOEs and the government, NSOEs are often in a disadvantaged position in the business environment because they face hidden constraints on investment and financing, industry admittance, and access to talent. To address these difficulties, NSOEs participate in charitable donations. Philanthropic activities make it easier for firms to establish political connections and help firms obtain greater legal protection. These activities benefit firms through increased investment, financing and tax 
incentives, and it further leads to a benign interaction between the government and society. Therefore, we propose the following hypothesis:

Hypothesis 2. Compared with SOEs, party committee governance significantly enhances the willingness to donate and the amount of donations by NSOEs, all else being equal.

Party committees tend to make the appropriate decision-making in line with the institutional environment. When the region where the firm is located has a high level of marketization, the market mechanism is perfect, and market information can be delivered in a timely and effective manner. The firms with a better demonstration of social responsibility are more likely to obtain a good market reputation. For this reason, a firm will fulfill social responsibility actively to convey a good corporate image. Therefore, the following hypothesis is put forward:

Hypothesis 3. Party committee governance significantly enhances the willingness to donate and the amount of donations in the regions with higher marketization level, all else being equal.

Industries with a high degree of monopoly receive support from government departments in the forms of permission and protection [33]. This implies that suppliers of similar products or services pose a weak threat, and the monopoly has strong bargaining power, which results in a better business performance. At the same time, if customers have formed strong loyalty to the firm's products, this weakens the firm's incentives to assume corporate social responsibility. Given the above reasoning, we propose the following hypothesis:

Hypothesis 4. The effect of party committee governance on corporate charitable donations is reduced by the degree of market monopoly, all else being equal.

\section{Data and Methodology}

\subsection{Samples and Data}

We used 16 polluting industries published by the Ministry of Ecology and Environment as samples to construct a panel dataset that consisted of firm-year observations of listed companies in China from 2013 to 2018. The samples were selected for two reasons. First, since the 18th National Congress of the CPC, the party central committee put forward a number of new requirements for environmental protection. Therefore, we started the research year from 2013. Second, 2018 was adopted as the end year of the sample period because of availability of data on corporate charitable donations and party committees. We further filtered the samples by excluding both firms with incomplete party committee data and with missing corporate charitable donation data. There were 1701 samples, and the data for party committees were collected manually by sorting through the annual reports of the firms and official websites. The corporate charitable donation data came from the China Securities Market and Accounting Research (CSMAR) database. We also minorized the main successive variables at the $1 \%$ and $99 \%$ levels to mitigate the effect of outliers. The results were analyzed using Stata15.0.

\subsection{Model and Variable Definition}

Whether the chairman of the board concurrently serves as the secretary of the party committee was used to measure the party committee's participation in corporate governance [29]. If the secretary of the party committee concurrently served as the chairman of the board, the party committee variable took the value 1 , and zero otherwise. In the party committee, the secretary undertakes the kernel role, who presides over the general work of the enterprise party committee. Therefore, we focused on how the chairman who served as party secretary affected the charitable donation behavior of heavy- pollution industries.

We measured charitable donation behavior with both dummy variables and the amount of charitable donations. For dummy variables, if a company made charitable 
donations this year, the value was 1 or zero otherwise. For the second measurement, we used the logarithm values of the actual amount of charitable donations. Referring to the studies of Yu et al. [28], we defined a set of control variables, which included enterprise size (Ln_asset), profitability (ROA), solvency (Lev), enterprise ownership (SOE), whether it was auditable by the Big Four (Big4), and whether the chairman and manager were combined (Dual). We implemented the following panel data model:

$$
\begin{aligned}
& \text { Isdonation }_{i, t}=\alpha_{0}+\alpha_{1} \text { Dzz }_{i, t}+\alpha_{2} \text { controls }_{i, t}+\varepsilon_{i, t} \\
& \text { Lndonation }_{i, t}=\alpha_{0}+\alpha_{1} \text { Dzz }_{i, t}+\alpha_{2} \text { controls }_{i, t}+\varepsilon_{i, t}
\end{aligned}
$$

where Equation (1) denotes the effect of party committee governance on corporate willingness to engage in charitable donations. Equation (2) indicates the effect of party committee on the amount of corporate charitable donations.

To investigate the moderating effect of monopoly intensity on the relationship between party committee and corporate charitable donations, we constructed the following model:

$$
\text { Isdonation }_{i, t}=\alpha_{0}+\alpha_{1} D z z_{i, t}+\gamma D z z * \text { Lerner }+\alpha_{2} \text { Lerner }+\alpha_{3} \text { controls }_{i, t}+\varepsilon_{i, t}
$$

\begin{tabular}{|c|c|c|}
\hline Variables Category & Symbol & Definitions \\
\hline Charitable donation & Isdonation & $\begin{array}{l}\text { It is a dummy variable that equals } 1 \text { if the company has } \\
\text { made a charitable donation and zero otherwise. }\end{array}$ \\
\hline Charitable donation amount & $\begin{array}{l}\text { Lndonation } \\
\text { donation }\end{array}$ & $\begin{array}{l}\text { Natural logarithm of corporate charitable donations. } \\
\text { Corporate charitable donation amount/operating } \\
\text { income } * 1000 .\end{array}$ \\
\hline $\begin{array}{l}\text { Party organization } \\
\text { governance }\end{array}$ & Dzz & $\begin{array}{l}\text { It is a dummy variable that equals } 1 \text { if the chairman of } \\
\text { the board is concurrently the secretary of the party } \\
\text { committee and zero otherwise. }\end{array}$ \\
\hline Enterprise size & Lnasset & $\begin{array}{c}\text { Natural logarithm of the firm's total assets at the fiscal } \\
\text { year end. }\end{array}$ \\
\hline Profitability & $\mathrm{ROA}$ & $\begin{array}{l}\text { Net income during the fiscal year divided by total assets } \\
\text { at the fiscal year end. }\end{array}$ \\
\hline Solvency & Lev & The ratio of total debt to total assets at the fiscal year end. \\
\hline Enterprise' ownership & SOE & $\begin{array}{c}\text { SOE is 1if the company is a state-owned enterprise and } \\
\text { zero otherwise. }\end{array}$ \\
\hline $\begin{array}{l}\text { Whether the accounting firm } \\
\text { employed is one of the Big } \\
\text { Four }\end{array}$ & Big4 & $\begin{array}{l}\text { The Big4 is } 1 \text { if the firm selected by the company belongs } \\
\text { to the Big Four accounting firm, and zero otherwise. }\end{array}$ \\
\hline $\begin{array}{l}\text { Whether the chairman and } \\
\text { manager are the same person }\end{array}$ & Dual & $\begin{array}{c}\text { The Dual value is } 1 \text { if the chairman is concurrently the } \\
\text { general manager and two otherwise. }\end{array}$ \\
\hline $\begin{array}{c}\text { The largest shareholder's } \\
\text { shareholding ratio }\end{array}$ & First & $\begin{array}{c}\text { The percentage of shares held by top } 1 \text { shareholder in } \\
\text { total holdings. }\end{array}$ \\
\hline Enterprise establishment time & Lntime & Natural logarithm of company establishment time. \\
\hline Marketization level & Market & $\begin{array}{c}\text { China's regional marketization index compiled by Fan } \\
\text { Gang and Wang Xiaolu. }\end{array}$ \\
\hline Degree of monopoly & $\begin{array}{l}\text { IndustryLerner } \\
\text { EnterpriseLerner }\end{array}$ & $\begin{array}{l}\text { Industry Lerner Index; } \\
\text { Enterprise Lerner Index. } \\
\text { If the company is located in the eastern part of China, the }\end{array}$ \\
\hline Region & Region & $\begin{array}{l}\text { If the company is located in the eastern part of China, the } \\
\text { Region is one; if it is located in the central region, the } \\
\text { region is two; otherwise, the Region is zero. }\end{array}$ \\
\hline Year & Year & Dummy for year. \\
\hline
\end{tabular}

All variables for Equations (1)-(3) are defined in Table 2.

Table 2. Definition of variables.

\subsection{Descriptive Statistics}

The mean level of willingness to donate (Isdonation) was 0.638 , and the amount of charitable donations (Lndonation) was 8.292, with standard deviations of 0.481 and 6.549, respectively (Table 3). Nearly $65 \%$ of the companies in the sample participated in charitable donations. The minimum and maximum values of the amount of donations (Lndonation) were 0 and 16.817, respectively, which demonstrated the significant differences in the amount of charitable donations across companies. The average value of the one person 
who concurrently served the positions of party committee secretary and the chairman of the board $(D z z)$ reached 0.453 . The minimum value for the regional marketization index was 3.130 and the maximum value was 10.620 , which showed the great differences in the level of marketization across various regions in China. The minimum and maximum values of $R O A$ were -0.095 and 0.192 , respectively. Similarly, the minimum and maximum of Lev, Lntime, and Lnasset also indicated the great differences among firms.

Table 3. Descriptive statistics.

\begin{tabular}{|c|c|c|c|c|c|c|c|c|}
\hline \multirow{3}{*}{ Variables } & \multicolumn{6}{|c|}{ Full Sample } & \multirow{2}{*}{$\begin{array}{c}\mathrm{Dzz}=0 \\
\mathrm{~N}=930 \\
\text { Mean }\end{array}$} & \multirow{2}{*}{$\begin{array}{c}\mathrm{Dzz}=1 \\
\mathrm{~N}=771 \\
\text { Mean }\end{array}$} \\
\hline & \multirow{2}{*}{$\begin{array}{c}\text { Obs } \\
(1)\end{array}$} & \multirow{2}{*}{$\begin{array}{c}\text { Mean } \\
(2)\end{array}$} & \multirow{2}{*}{$\begin{array}{l}\text { Full } \\
\text { Sd } \\
\text { (3) }\end{array}$} & \multirow{2}{*}{$\begin{array}{c}\text { Min } \\
(4)\end{array}$} & \multirow{2}{*}{$\begin{array}{c}\text { Median } \\
(5) \\
\end{array}$} & \multirow{2}{*}{$\begin{array}{c}\text { Max } \\
(6)\end{array}$} & & \\
\hline & & & & & & & (7) & (8) \\
\hline Isdonation & 1701 & 0.638 & 0.481 & 0 & 1 & 1 & 0.581 & $0.707^{* * *}$ \\
\hline donation & 1701 & 0.242 & 0.565 & 0 & 0.022 & 3.586 & 0.235 & 0.249 \\
\hline Lndonation & 1701 & 8.292 & 6.549 & 0 & 11.562 & 16.817 & 7.525 & $9.219^{* * *}$ \\
\hline Dzz & 1701 & 0.453 & 0.498 & 0 & 0 & 1 & 0 & 1 \\
\hline Big4 & 1701 & 0.076 & 0.266 & 0 & 0 & 1 & 0.073 & 0.080 \\
\hline Dual & 1701 & 1.844 & 0.363 & 1 & 2 & 2 & 1.834 & 1.856 \\
\hline Market & 1701 & 7.807 & 1.920 & 3.130 & 7.600 & 10.620 & 7.755 & 7.871 \\
\hline First & 1701 & 36.762 & 14.595 & 10.720 & 35.490 & 75.250 & 36.209 & 37.429 * \\
\hline SOE & 1701 & 0.617 & 0.486 & 0 & 1 & 1 & 0.548 & $0.700^{* * *}$ \\
\hline ROA & 1701 & 0.040 & 0.047 & -0.095 & 0.033 & 0.192 & 0.041 & 0.039 \\
\hline Lev & 1701 & 0.441 & 0.194 & 0.019 & 0.441 & 1.352 & 0.424 & $0.461^{* * *}$ \\
\hline Lntime & 1701 & 2.859 & 0.292 & 1.946 & 2.890 & 3.367 & 2.845 & $2.876^{* *}$ \\
\hline Lnasset & 1701 & 22.688 & 1.277 & 20.348 & 22.501 & 26.175 & 22.556 & $22.848^{* * *}$ \\
\hline
\end{tabular}

Note: Average difference test is carried out here according to whether the chairman is concurrently party secretary or not; ${ }^{* * *}, * * *$ denote significance at the $10 \%, 5 \%$, and $1 \%$ levels respectively.

The mean difference between chairmen who concurrently held the post of party secretary and chairmen who concurrently did not hold the post of party secretary showed that for both corporate charitable donations (Isdonation) and amount of charitable donations (Lndonation), the index of chairmen who concurrently held the post of party secretary was significantly higher (Table 3). Most of the mean difference tests for control variables were significant, which indicated that the control variables that we selected were reasonable.

\subsection{Correlation Analysis}

The correlation coefficient between the party committee governance $(D z z)$ and the willingness of a corporation to donate (Isdonation) was 0.131 , and the correlation coefficient with the corporate donation amount (Lndonation) was 0.129 ; both were significantly correlated at the 1\% level (Table 4). Enterprise size (Lnasset), dual occupation (Dual), ratio of largest shareholder (First), and time of company establishment (Lntime) were correlated significantly with willingness to donate (Isdonation) and amount of corporate donations (Lndonation). The correlation coefficient between Lndonation and Isdonation was 0.942 . The correlation among the control variables was modest, with correlation coefficients generally $<0.5$, which suggested minimal multicollinearity problems. 
Table 4. Pearson correlation matrix.

\begin{tabular}{|c|c|c|c|c|c|c|c|c|c|c|c|}
\hline Variables & Isdo-Nation & $\begin{array}{l}\text { Lndo- } \\
\text { Nation }\end{array}$ & Dzz & Lnas-Set & ROA & Lev & Big4 & Dual & First & SOE & $\begin{array}{l}\text { Lnti- } \\
\text { Me }\end{array}$ \\
\hline Isdonation & 1 & & & & & & & & & & \\
\hline Lndonation & $0.942 * * *$ & 1 & & & & & & & & & \\
\hline Dzz & $0.131^{* * *}$ & $0.129 * * *$ & 1 & & & & & & & & \\
\hline Lnasset & $0.149^{* * *}$ & $0.207^{* * *}$ & $0.114^{* * *}$ & 1 & & & & & & & \\
\hline ROA & $-0.040 *$ & -0.003 & -0.022 & $-0.079 * * *$ & 1 & & & & & & \\
\hline Lev & $0.097 * * *$ & $0.109 * * *$ & $0.096^{* * *}$ & $0.529^{* * *}$ & $-0.465^{* * *}$ & 1 & & & & & \\
\hline Big4 & 0.033 & $0.073^{* * *}$ & 0.014 & $0.366^{* * *}$ & 0.036 & $0.102 * * *$ & 1 & & & & \\
\hline Dual & $0.064^{* * *}$ & $0.067^{* * *}$ & 0.030 & $0.167 * * *$ & $-0.107^{* * *}$ & $0.145^{* * *}$ & 0.020 & 1 & & & \\
\hline First & $0.071^{* * *}$ & $0.066^{* * *}$ & $0.042 *$ & $0.322 * * *$ & 0.010 & $0.117^{* * *}$ & $0.091^{* * *}$ & 0.027 & 1 & & \\
\hline SOE & 0.031 & 0.020 & $0.156^{* * *}$ & $0.272 * * *$ & $-0.176^{* * *}$ & $0.309^{* * *}$ & $0.049 * *$ & $0.215^{* * *}$ & $0.199 * * *$ & 1 & \\
\hline Lntime & $-0.144^{* * *}$ & $-0.136^{* * *}$ & $0.052 * *$ & $0.114^{* * *}$ & -0.025 & $0.137^{* * *}$ & 0.015 & $0.045^{*}$ & $-0.104^{* * *}$ & $0.226^{* * *}$ & 1 \\
\hline
\end{tabular}

Note: ${ }^{* * *}, * *$, and $*$ denote significance at the $1 \%, 5 \%$, and $10 \%$ level, respectively.

\section{Empirical Results}

\subsection{Baseline Regression Results}

We employed the Logit model and the Tobit model for regression. After controlling for year- and region-fixed effects, the sample data were clustered at the company level to control for heteroscedasticity. Corporate party committees had a negative effect on willingness of a corporation to give charitable donations because the estimated coefficient of $D z z$ was 1.5748 with a $t$-statistic of 0.26 , which was significant at the $1 \%$ level (Table 5). Corporate party committees had a similar effect on the amount of charitable donations, with a coefficient of $2.9857(t$-statistic $=0.61)$. Therefore, Hypothesis 1 was supported. As the party secretary, the chairman's political awareness was enhanced, which led to increases in the company's willingness to donate and in the amount of the company's charitable donations. For the control variables, there was a positive correlation between total assets and Isdonation and Lndonation, but the firm's ownership was correlated negatively with Isdonation and Lndonation.

Table 5. Baseline regression results.

\begin{tabular}{ccc}
\hline \multirow{2}{*}{ Variables } & $\mathbf{( 1 )}$ & $\mathbf{( 2 )}$ \\
\cline { 2 - 3 } Dzz & Isdonation & Lndonation \\
\hline Lnasset & $1.5748^{* * *}$ & $2.9857^{* * *}$ \\
& $(0.26)$ & $(0.61)$ \\
ROA & $0.8130 * * *$ & $2.0022^{* * *}$ \\
& $(0.15)$ & $(0.38)$ \\
Lev & 0.0841 & 9.6105 \\
& $(2.51)$ & $(7.79)$ \\
Big4 & -0.5073 & -0.4666 \\
& $(0.86)$ & $(2.34)$ \\
Dual & -0.5188 & -1.1299 \\
& $(0.56)$ & $(1.45)$ \\
First & 0.2250 & 0.6012 \\
& $(0.31)$ & $(0.93)$ \\
SOE & 0.0045 & -0.0112 \\
& $(0.01)$ & $(0.02)$ \\
Lntime & $-0.7594 * *$ & $-2.0662 * *$ \\
& $(0.31)$ & $(0.76)$ \\
cons & -0.6467 & $-1.8882 *$ \\
& $(0.52)$ & $(1.11)$ \\
Region & $-14.4698 * * *$ & $-31.1252^{* * *}$ \\
Year & $(3.29)$ & $(8.28)$ \\
Pseudo R2 & Yes & Yes \\
N & Yes & Yes \\
Note: *****, and ${ }^{*}$ denote significance at the $1 \%, 5 \%$, and $10 \%$ level, respectively. & 0.0659 \\
& & 1701 \\
\hline
\end{tabular}

Note: ${ }^{* * *},{ }^{* *}$, and ${ }^{*}$ denote significance at the $1 \%, 5 \%$, and $10 \%$ level, respectively. 


\subsection{Cross-Sectional Analysis}

Our primary findings of the relationship between the party committee governance and corporate charitable donations may have depended on specific firm or regional characteristics. To investigate these issues, we conducted a cross-sectional analysis based on the sub-samples of firms with different levels of ownership, marketization, or monopolization.

First, we subdivided the sample companies into SOEs and NSOEs, and then used Equations (1) and (2) (Table 6). Party committee governance in both SOEs and NSOEs increased the willingness to donate significantly, with coefficients of 1.3242 and 1.5719 , respectively. As for the NSOEs, chairmen served as the secretary of the party committee. He was aware of social responsibility and increased charitable donations because of his political status. This charitable behavior shaped the company's image by improving their unfavorable situation in financing, operations, and introduction of talent for the NSOEs. In contrast, the political attributes of SOEs weakened their motivation to establish political connections through donations. Party committee governance was correlated positively and significantly with the amount of corporate donations (Table 6). The estimated coefficients were 2.3416 for NSOEs and 3.0676 for SOEs, which was contrary to Hypothesis 2. We attributed the difference to the fact that Chinese SOEs were mostly distributed in important industries and key areas related to national security, such as energy, power, and postal services. They were more likely to gain financial support from the government and to enjoy policy preferences in terms of land, taxation, and credit, which led to more corporate donations. Moreover, SOEs, which bore the political mission to serve society, were sensitive to institutional pressure [34]. To cope with external pressure, SOEs had the motivation and ability to perform better in terms of the amount of charitable donations.

Table 6. The sub-sample regression results based on firm ownership.

\begin{tabular}{ccccc}
\hline \multirow{2}{*}{ Variables } & \multicolumn{2}{c}{ NSOEs } & \multicolumn{2}{c}{ SOEs } \\
\cline { 2 - 5 } & Isdonation & Lndonation & Isdonation & Lndonation \\
\hline Dzz & $1.5719^{* * *}$ & $2.3416^{* * *}$ & $1.3242^{* * *}$ & $3.0676^{* * *}$ \\
& $(0.38)$ & $(0.84)$ & $(0.34)$ & $(0.81)$ \\
_cons & -6.0427 & $-19.1663^{*}$ & $-17.6591^{* * *}$ & $-35.1526^{* * *}$ \\
& $(4.46)$ & $(11.06)$ & $(4.90)$ & $(11.36)$ \\
Control & Yes & Yes & Yes & Yes \\
Region & Yes & Yes & Yes & Yes \\
Year & Yes & Yes & Yes & Yes \\
Pseudo R & - & 0.0955 & - & 0.0556 \\
$\mathrm{~N}$ & 651 & 651 & 1050 & 1050 \\
\hline
\end{tabular}

Note: ${ }^{* *}$ and ${ }^{*}$ denote significance at the $1 \%$ and $10 \%$ level, respectively.

Next, we investigated the relationship between party committee governance and corporate charitable donations conditional on the level of marketization (Table 7). We divided the full sample according to the marketization index of the company's location. Values below the median were assigned a value of 0; otherwise, it was 1 . In regions with a low level of marketization, the coefficients of party committee governance for willingness to donate and amount of corporate donations were 0.9058 and 2.0082, respectively, and these were significant at the $1 \%$ level. In regions with a high level of marketization, the estimated coefficient of party committee governance on willingness to donate was 2.2016, and for the effect on amount of corporate donations, the estimated coefficient of party committee governance was 3.7732 , both of which were significant at the $1 \%$ level. 
Table 7. The sub-sample regression results based on marketization level.

\begin{tabular}{ccccc}
\hline \multirow{2}{*}{ Variables } & $\begin{array}{c}\mathbf{( 1 )} \\
\text { Market }=\mathbf{0}\end{array}$ & $\begin{array}{c}\mathbf{( 2 )} \\
\text { Market }=\mathbf{0}\end{array}$ & $\begin{array}{c}(\mathbf{3}) \\
\text { Market }=\mathbf{1}\end{array}$ & $\begin{array}{c}\mathbf{( 4 )} \\
\text { Market }=\mathbf{1}\end{array}$ \\
\cline { 2 - 5 } & Isdonation & Lndonation & Isdonation & Lndonation \\
\hline Dzz & $0.9058^{* * *}$ & $2.0082^{* *}$ & $2.2016^{* * *}$ & $3.7732^{* * *}$ \\
& $(0.35)$ & $(0.87)$ & $(0.37)$ & $(0.78)$ \\
_cons & $-12.6134^{* * *}$ & $-38.5269^{* * *}$ & $-15.8908^{* * *}$ & $-25.1084^{* *}$ \\
& $(4.20)$ & $(10.90)$ & $(4.94)$ & $(11.42)$ \\
Control & Yes & Yes & Yes & Yes \\
Region & Yes & Yes & Yes & Yes \\
Year & Yes & Yes & Yes & Yes \\
Pseudo $R^{2}$ & - & 0.0696 & - & 0.0708 \\
$\mathrm{~N}$ & 851 & 851 & 850 & 850 \\
\hline Note: & & & &
\end{tabular}

Hypothesis 3 was supported. This implied that in areas with a high degree of marketization, party committee governance had a significant impact on corporate charitable donations. We believed this was true because in these areas, the market played a greater role in the allocation of resources, various production factors flowed flexibly, and market information was disseminated quickly and widely. Charitable donations of firms should be conducive to establishing a good corporate image. Meanwhile, a high level of marketization meant that the public had a strong environmental awareness, which encouraged strict requirements for corporate donations. For this reason, firms had a stronger motivation to make donations.

To examine the effects of monopolization, we finally introduced the interaction items between the industry Lerner index and party committee governance and the interaction items between the company's Lerner index and party committee governance (Table 8).

Table 8. The moderating effect of monopolization.

\begin{tabular}{ccccc}
\hline \multirow{2}{*}{ Variables } & $\mathbf{( 1 )}$ & $\mathbf{( 2 )}$ & $\mathbf{( 3 )}$ & $\mathbf{( 4 )}$ \\
\cline { 2 - 5 } & Isdonation & Lndonation & Isdonation & Lndonation \\
\hline Dzz & $1.9828^{* * *}$ & $3.5255^{* * *}$ & $2.1974 * * *$ & $4.6850^{* * *}$ \\
& $(0.49)$ & $(1.18)$ & $(0.45)$ & $(0.95)$ \\
IndustryLerner & -3.9007 & -10.6923 & & \\
& $(2.47)$ & $(7.65)$ & & \\
interact & -3.3325 & -4.3192 & $-5.0474^{*}$ & $-13.8956^{* *}$ \\
& $(3.30)$ & $(9.10)$ & $(2.85)$ & $(6.30)$ \\
EnterpriseLerner & & & -2.4834 & -1.2036 \\
& & & $(1.56)$ & $(5.07)$ \\
cons & $-14.8755^{* * *}$ & $-32.2782 * * *$ & -15.9074 & $-33.1478^{* * * *}$ \\
Control & $(3.30)$ & $(8.55)$ & $(3.39)$ & $(8.71)$ \\
Region & Yes & Yes & Yes & Yes \\
Year & Yes & Yes & Yes & Yes \\
Pseudo $\mathrm{R}^{2}$ & Yes & Yes & Yes & Yes \\
$\mathrm{N}$ & - & 0.0676 & - & 0.0670 \\
\hline Note: $* * * * *$ & and ${ }^{*}$ denote significance at the $1 \%, 5 \%$, and $10 \%$ level, respectively. & 1701 \\
\hline
\end{tabular}

Evidently, after adding the interaction term of industry and enterprise Lerner index respectively, the party committee governance still had positive effects on the willingness and amount of corporate charitable donations, which was significant at the $1 \%$ level. However, the Industry Lerner and the Enterprise Lerner were correlated negatively with the willingness and amount of corporate charitable donations. The regression coefficient of the interaction term between the corporate Lerner index and party committee governance on corporate charitable donations was -13.8956 , which was significant at the $5 \%$ level. 
Therefore, Hypothesis 4 was supported. The higher Lerner index of a company indicated its stronger monopoly power, which weakened the company's motivation to improve its market position through charitable donations. Therefore, the degree of monopoly regulated the relationship between party committee governance and charitable donations negatively.

\section{Robustness Test}

\subsection{Alternative Variable Definitions}

We conducted robustness checks by replacing the explained variable with donations (Table 9); that is, the company's amount of charitable donations was divided by the firm's operating income for that year and then multiplied by 1000. This measurement aimed to mitigate the impact of firm size and to eliminate the differentials. Additionally, we used one-year lagged party committee governance as an explanatory variable to address the endogeneity issue. The positive coefficients were consistent with the previous conclusions, which showed the robust results.

Table 9. Alternative variable definitions.

\begin{tabular}{cccc}
\hline \multirow{2}{*}{ Variables } & $\mathbf{( 1 )}$ & $\mathbf{( 2 )}$ & $\mathbf{( 3 )}$ \\
\cline { 2 - 4 } & Donation & Isdonation & Lndonation \\
\hline Dzz & $0.1605^{* * *}$ & & \\
L.Dzz & $(0.06)$ & & $2.5033^{* * *}$ \\
& & $1.3596^{* * *}$ & $(0.74)$ \\
cons & -1.1936 & $-11.7360^{* * *}$ & $-26.5386^{* * *}$ \\
Control & $(0.77)$ & $(3.94)$ & $(9.94)$ \\
Region & Yes & Yes & Yes \\
Year & Yes & Yes & Yes \\
Pseudo $\mathrm{R}^{2}$ & Yes & Yes & 0.0627 \\
$\mathrm{~N}$ & 0.0827 & - & 1188 \\
\hline Note: ${ }^{* * *}$ denotes significance at the $1 \%$ level. & 1188 &
\end{tabular}

\subsection{Propensity Score Matching}

We used Propensity Score Matching (PSM) to estimate the effect of party committee governance based on whether the chairman also served as the party secretary. Before the estimation of PSM, we performed a balance test. The standard deviation of all variables after matching was controlled significantly within $10 \%$. The standardized deviations of all variables were reduced, and the t-tests did not reject the null hypothesis that there was no systematic difference between the treatment group and the control group. All variables were significant at the $1 \%$ level, which showed that after propensity score matching, the differences in indicators other than party committee governance were controlled significantly.

Columns 1-Columns 7 in Table 10 respectively report the estimation results of party committee governance using one-to-one matching, proximity matching, caliper matching, radius matching, kernel matching, local linear regression matching, and spline matching methods for corporate charitable donations. ATE represents the matching result of the total sample, ATU indicates that the matching result of the chairmen who were not concurrently serving as the party secretary, and ATT is the average processing effect of the chairmen who concurrently served as the secretary of the party committee. The results showed that party committee governance significantly increased the amount of charitable donations by about 1.8 times. The estimation result of PSM was basically consistent with the previous conclusion. That is, party committee governance significantly increased the amount of corporate charitable donations. 
Table 10. Propensity score matching.

\begin{tabular}{|c|c|c|c|c|c|c|c|}
\hline & Model 1 & Model 2 & Model 3 & Model 4 & Model 5 & Model 6 & Model 7 \\
\hline $\begin{array}{l}\text { Dependent } \\
\text { Variable }\end{array}$ & & & & Dzz & & & \\
\hline $\begin{array}{l}\text { Estimation } \\
\text { Methods }\end{array}$ & $\begin{array}{l}\text { One-to-One } \\
\text { Matching }\end{array}$ & $\begin{array}{l}\text { Proximity } \\
\text { Matching }\end{array}$ & $\begin{array}{l}\text { Caliper } \\
\text { Matching }\end{array}$ & $\begin{array}{c}\text { Radius } \\
\text { Matching }\end{array}$ & $\begin{array}{c}\text { Kernel } \\
\text { Matching }\end{array}$ & $\begin{array}{l}\text { Local Linear } \\
\text { Regression } \\
\text { Matching }\end{array}$ & $\begin{array}{c}\text { Spline } \\
\text { Matching }\end{array}$ \\
\hline ATT & $\begin{array}{c}1.3520 * * \\
(0.44)\end{array}$ & $\begin{array}{c}1.6401^{* * *} \\
(0.46)\end{array}$ & $\begin{array}{c}1.6431^{* * * *} \\
(0.34)\end{array}$ & $\begin{array}{c}1.8461^{* * *} \\
(0.33)\end{array}$ & $\begin{array}{c}1.8066^{* * *} \\
(0.30)\end{array}$ & $\begin{array}{c}1.8199 * * * \\
(0.32)\end{array}$ & $\begin{array}{c}1.7428^{* * *} \\
(0.32)\end{array}$ \\
\hline ATU & $\begin{array}{l}1.9292^{* * *} \\
(0.45)\end{array}$ & $\begin{array}{c}1.7714^{* * *} \\
(0.43)\end{array}$ & $\begin{array}{c}1.7714^{* * *} \\
(0.37)\end{array}$ & $\begin{array}{c}1.7320^{* * * *} \\
(0.33)\end{array}$ & $\begin{array}{c}1.7812^{* * *} \\
(0.28)\end{array}$ & $\begin{array}{c}1.8236^{* * *} \\
(0.30)\end{array}$ & $\begin{array}{c}1.7334^{* * * *} \\
(0.32)\end{array}$ \\
\hline ATE & $\begin{array}{c}1.6651 \text { *** } \\
(0.32)\end{array}$ & $\begin{array}{c}1.7113^{* * * *} \\
(0.39)\end{array}$ & $\begin{array}{c}1.7127^{* * * *} \\
(0.30)\end{array}$ & $\begin{array}{c}1.7842^{* * * *} \\
(0.28)\end{array}$ & $\begin{array}{c}1.7928^{* * *} \\
(0.28)\end{array}$ & $\begin{array}{c}1.8219^{* * *} \\
(0.29)\end{array}$ & $\begin{array}{c}1.7377^{* * * *} \\
(0.30)\end{array}$ \\
\hline $\mathrm{N}$ & 1701 & 1701 & 1701 & 1701 & 1701 & 1701 & 1701 \\
\hline
\end{tabular}

Note: Model 1 to Model 7 represent different matching methods. The standard deviations reported in the table are all obtained by the self-help method. ${ }^{* * *}$ and ${ }^{* *}$ represent the significance levels of $1 \%$ and $5 \%$, respectively. T-statistics are reported in parentheses.

\section{Conclusions and Policy Recommendations}

This paper provides novel evidence of how corporate party committee governance affected charitable donations in heavy-pollution industries. Party committee governance significantly enhanced the willingness to donate and the amount of donations. According to the heterogeneity tests of ownership, party committee governance had significant positive effects on non-state-owned firms in terms of willingness to donate, but for the donation amount, party committee governance had a more significant promoting effect on stateowned firms. Party committee governance increased the amount of charitable donations in the regions with a higher level of marketization, and the strength of the firm's monopoly moderated the relationship negatively.

Compared with other research, our study documents specific results: First, different from the existing research that has confirmed the positive effects of corporate party committee governance on loss of state-owned assets [24], social responsibility behavior [26,28], and executive compensation [29], our study focused on heavy-pollution industries and highlighted the significant correlation between corporate party committee governance and charitable donations. Second, previous studies demonstrated the contradictory role of monopoly in promoting donations [35]. However, our results suggested that the degree of monopoly moderated the relationship between corporate party committee governance and charitable donations negatively.

Our findings have several policy implications. First of all, the functions of party committee governance with respect to corporate social responsibility should be strengthened. As the critical industries of the national economy, high polluting industries should show greater concern for the duties of corporate party committees. To meet the Communist Party Constitution, Company Law, and other regulatory requirements, corporate party committee governance should take an active role to promote the decision-making of corporate social responsibility through "environmental compensation".

Our results also highlighted the importance of improving the business environment and increasing charitable donations in underdeveloped areas. The business environment varied across regions, which was highlighted by the levels of marketization. Our results revealed that the level of marketization significantly affected the influence of party committee governance on charitable donation of heavy-pollution industries. To promote fairness and efficiency, the government should remove the barriers that hinder the balanced development of regions [36,37]. For this reason, differential regional development strategies that focus on investment in human capital, technological innovation, and infrastructure should be formulated. Cross-regional cooperation should be enhanced to improve the level of marketization in economically backward areas.

Moreover, our results showed the necessity of breaking the monopoly of heavypollution industries and increasing the efficiency of market competition. Among the 
heavy-pollution industries, the industries of petrochemicals and thermal power generation had a strong monopoly, which moderated the effects of communist party committees negatively. Therefore, breaking the monopoly of these industries and introducing a market competition mechanism are critical. The government should distinguish between a natural monopoly and competitive businesses in monopoly industries by liberalizing market access for competitive businesses. To stimulate market vitality and to promote fair competition, the government should speed up the mixed ownership reform of SOEs by introducing private capital in industries, such as electric power and petroleum.

Finally, the government should continue to encourage the enthusiasm of SOEs to donate and to increase financial support for NSOEs. As the major polluters, heavy-pollution industries should actively assume social responsibility through "environmental compensation". As a result of the insufficient willingness to donate for a few SOEs, these SOEs should strengthen the political role of party committee governance by educating the employees of SOEs and propagandizing corporate social responsibility. For NSOEs with a low level of donations, the government needs to eliminate barriers for the market environment and the legal environment. The government should increase financial support, guide credit resources to NSOEs, reduce financial pressure of their charitable donations, and provide a fair business environment for them.

Author Contributions: Conceptualization, H.Z.; methodology, supervision, writing-reviewing and editing, validation, L.L.; methodology, data curation, software, writing-original draft, C.F.; conceptualization, editing, Z.H.; data curation, H.u.R.K. All authors have read and agreed to the published version of the manuscript.

Funding: This research was funded by grants from the National Social Science Fund of China (Funding name: The subsidy reduction path and mechanism design of new energy targeted poverty alleviation in China. Grant No. 19BGL185).

Institutional Review Board Statement: Not applicable.

Informed Consent Statement: Not applicable.

Data Availability Statement: The data presented in this study are available on request from the corresponding author.

Conflicts of Interest: The authors declare no conflict of interest.

\section{References}

1. Du, X.; Chang, Y.; Zeng, Q.; Du, Y.; Pei, H. Corporate environmental responsibility (CER) weakness, media coverage, and corporate philanthropy: Evidence from China. Asia Pac. J. Manag. 2015, 33, 551-581. [CrossRef]

2. Campbell, L.; Gulas, C.S.; Gruca, T. Corporate Giving Behavior and Decision-Maker Social Consciousness. J. Bus. Ethics 1999, 19, 375-383. [CrossRef]

3. Frey, B.S.; Meier, S. Pro-Social behavior in a natural setting. J. Econ. Behav. Organ. 2004, 54, 65-88. [CrossRef]

4. Jamal, A.; Yaccob, A.; Bartikowski, B.; Slater, S. Motivations to donate: Exploring the role of religiousness in charitable donations. J. Bus. Res. 2019, 103, 319-327. [CrossRef]

5. Su, Z.-Q.; Xu, Y.; Xiao, Z.; Fung, H.-G. Directors' prior life experience and corporate donations: Evidence from China. N. Am. J. Econ. Financ. 2020, 53, 101191. [CrossRef]

6. Ballings, M.; McCullough, H.; Bharadwaj, N. Cause marketing and customer profitability. J. Acad. Mark. Sci. 2017, 46, 234-251. [CrossRef]

7. Cheung, A.; Pok, W.C. Corporate social responsibility and provision of trade credit. J. Contemp. Account. Econ. 2019, 15, 100159. [CrossRef]

8. Islam, T.; Islam, R.; Pitafi, A.H.; Xiaobei, L.; Rehmani, M.; Irfan, M.; Mubarak, M.S. The impact of corporate social responsibility on customer loyalty: The mediating role of corporate reputation, customer satisfaction, and trust. Sustain. Prod. Consum. 2020, 25, 123-135. [CrossRef]

9. Dang, V.T.; Nguyen, N.; Pervan, S. Retailer corporate social responsibility and consumer citizenship behavior: The mediating roles of perceived consumer effectiveness and consumer trust. J. Retail. Consum. Serv. 2020, 55, 102082. [CrossRef]

10. Luo, J.; Liu, Q. Corporate social responsibility disclosure in China: Do managerial professional connections and social attention matter? Emerg. Mark. Rev. 2020, 43, 100679. [CrossRef]

11. Hu, J.; Wu, H.; Ying, S.X.; Long, W. Relative-to-Rival corporate philanthropy, product market competitiveness, and stakeholders. J. Contemp. Account. Econ. 2020, 17, 100237. [CrossRef] 
12. Houqe, M.N.; van Zijl, T.; Karim, A.W.; George, T.S. The value relevance of corporate donations. Pac. Basin Financ. J. 2019, 66, 101127. [CrossRef]

13. Shiu, Y.-M.; Yang, S.-L. Does engagement in corporate social responsibility provide strategic insurance-like effects? Strat. Manag. J. 2015, 38, 455-470. [CrossRef]

14. Hogarth, K.; Hutchinson, M.; Scaife, W. Corporate Philanthropy, Reputation Risk Management and Shareholder Value: A Study of Australian Corporate giving. J. Bus. Ethics 2016, 151, 375-390. [CrossRef]

15. Agarwal, V.; Lu, Y.; Ray, S. Are hedge funds' charitable donations strategic? J. Corp. Financ. 2020, 66, 101842. [CrossRef]

16. Xia, X.; Teng, F.; Gu, X. Reputation repair and corporate donations: An investigation of responses to regulatory penalties. China J. Account. Res. 2019, 12, 293-313. [CrossRef]

17. Chen, H.; Guo, Y.; Wen, Q. For goodwill or resources? The rationale behind firms' corporate philanthropy in an environment with high economic policy uncertainty. China Econ. Rev. 2020, 65, 101580. [CrossRef]

18. Campbell, J.L. Why would corporations behave in socially responsible ways? An institutional theory of corporate social responsibility. Acad. Manag. Rev. 2007, 32, 946-967. [CrossRef]

19. Liu, W.; De Sisto, M.; Li, W.H. How does the turnover of local officials make firms more charitable? A comprehensive analysis of corporate philanthropy in China. Emerg. Mark. Rev. 2020, 46, 100748. [CrossRef]

20. Qian, W.; Chen, X. Corporate environmental disclosure and political connection in regulatory and leadership changes: The case of China. Br. Account. Rev. 2020, 53, 100935. [CrossRef]

21. Muttakin, M.B.; Mihret, D.G.; Khan, A. Corporate political connection and corporate social responsibility disclosures: A neo-pluralist hypothesis and empirical evidence. Account. Audit. Account. J. 2018, 31, 725-744. [CrossRef]

22. Zhang, J.; Marquis, C.; Qiao, K. Do Political Connections Buffer Firms from or Bind Firms to the Government? A Study of Corporate Charitable Donations of Chinese Firms. Organ. Sci. 2016, 27, 1307-1324. [CrossRef]

23. Chang, E.C.; Wong, S.M. Political control and performance in China's listed firms. J. Comp. Econ. 2004, 32, 617-636. [CrossRef]

24. Chen, S.; Lu, C. Can the governance participation of state-owned enterprise party organizations effectively curb the "loss of state-owned assets" in mergers and acquisitions? Manag. World 2014, 5, 106-120. (In Chinese)

25. Guo, H.; Li, W.; Zhong, Y. Political involvement and firm performance-Chinese setting and cross-country evidence. J. Int. Financ. Mark. Inst. Money 2018, 59, 218-231. [CrossRef]

26. Zheng, D.; Xie, D. Party organizations and corporate donations in non-public enterprises. J. Financ. Res. 2019, 9, 151-168. (In Chinese)

27. Gustafsson, B.; Yang, X.; Shuge, G.; Jianzhong, D. Charitable donations by China's private enterprises. Econ. Syst. 2017, 41, 456-469. [CrossRef]

28. Yu, L.; Zhang, W.; Bi, Q. Party Organization Embeddedness and Corporate Social Responsibility. Collect. Essays Financ. Econ. 2019, 4, 61-70. (In Chinese)

29. Ma, L.; Wang, Y.; Shen, X. State-Owned enterprise party organization governance, redundant employees and executive compensation contracts. Manag. World 2013, 5, 100-115. (In Chinese)

30. Hambrick, D.C.; Mason, P.A. Upper Echelons: The Organization as a Reflection of Its Top Managers. Acad. Manag. Rev. 1984, 9 , 193-206. [CrossRef]

31. Di Giuli, A.; Kostovetsky, L. Are red or blue companies more likely to go green? Politics and corporate social responsibility. J. Financ. Econ. 2014, 111, 158-180. [CrossRef]

32. Jensen, M.C.; Meckling, W.H. Theory of the firm: Managerial behavior, agency costs and ownership structure. J. Financ. Econ. 1976, 3, 305-360. [CrossRef]

33. Du, W.; Li, M.; Wang, F. Role of rent-seeking or technological progress in maintaining the monopoly power of energy enterprises: An empirical analysis based on micro-data from China. Energy 2020, 202, 117763. [CrossRef]

34. Kansal, M.; Joshi, M.; Babu, S.; Sharma, S. Reporting of Corporate Social Responsibility in Central Public Sector Enterprises: A Study of Post Mandatory Regime in India. J. Bus. Ethics 2016, 151, 813-831. [CrossRef]

35. Krüger, P. Corporate goodness and shareholder wealth. J. Financ. Econ. 2015, 115, 304-329. [CrossRef]

36. Yan, D.; Kong, Y.; Ren, X.; Shi, Y.; Chiang, S. The determinants of urban sustainability in Chinese resource-based cities: A panel quantile regression approach. Sci. Total Environ. 2019, 686, 1210-1219. [CrossRef] [PubMed]

37. Cheng, C.; Ren, X.; Dong, K.; Dong, X.; Wang, Z. How does technological innovation mitigate CO2 emissions in OECD countries? Heterogeneous analysis using panel quantile regression. J. Environ. Manag. 2020, 280, 111818. [CrossRef] 